question will arise whether it is worth while to run mains from the nearest gas or electrical supply; or whether it is not more economical, for a temporary installation, to rely exclusively on portable illuminants such as those described in the earlier portion of the article, and to avoid the use of piping altogether.

The fact that petrol-air gas can be readily applied for heating is also an advantage, especially in laboratories where bunsen burners and small heating appliances are much used. In country houses petrol-air gas may also be used for small cooking ranges, the usual size of which consumes an amount of petrol equivalent to about twenty lights. Stoves for use in the fireplace to heat rooms can also be supplied, but as a rule the small householder finds it preferable to use a coal or wood fire rather than incur the expense of installing the exceptionally large plant necessary to heat a number of rooms.

There remain to be mentioned the systems of light-

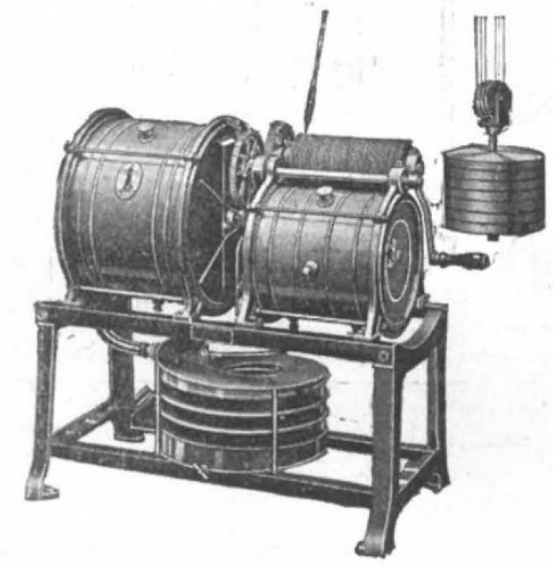

Fig. 4.-General view of Willett petrol-air gas plant. The plant consists of three chief parts-air compressor, petrol container, and spiral carburetter. The air compressor contains a cylindrical drum having in it a number of "scoops" so shaped as to produce a series of helical channels; the lower portion of the drum is filled with water. The petrol drum contains a number of small cups attached to the ends of rods which are fixed to revolving spindle. These cups discharge their contents into a funnelshaped receptacle, which in turn is controlled by the petrol regulator. Both the scoops in the air compressor and the spindle carrying the cups in the petrol drum are actuated by the suspended weight and work in perfect uniformity. The helical scoops in revolving take quantity of air which is helical scoops in revolving take up a measured tank at the air which is compressed and dischargen into a rectaneular tank at the side, from whence it passes into the carburetter. Meantime the carburetter receives a regulated amount of petrol in the manne described. The inter-connection of the apparatus for supplying air and petrol maintains the correct proportions of these constituents: no holde is needed to store the gas which is generated as required, the machine

ing and heating which generate gas from heavy oils, fats, etc., which require heat for distillation. These systems are claimed to be highly economical on a large scale, and are usually employed for large buildings, institutions, factories, country railway stations, etc. Many railways make their own oil gas, which is compressed and used for carriage lighting.

The Mansfield oil gas producer is widely used for generating this quality of gas, and is claimed to be applicable to a wide variety of fuels, such as creosote, palm oil, kerosene, and even tallow and unrefined fat. The oil is stored in a suitable tank and guided in a fine stream into a retort heated by a wood or coal fire. In this way a permanent oil gas is produced which, after purification, is stored in a holder and supplied through pipes in the usual way. The gas produced may be used either with incandescent mantles or in a flat flame burner. It may aIso be used for heating, having a high calorific power. In NO. 24 IO, VOL. 96] some cases a portion of the gas is used for cooking and heating water, and the remainder is utilised to drive an engine and dynamo, furnishing electric light. A system of this kind naturally requires some attention, but is claimed to be capable of being worked by unskilled labour, and to be very simple in operation.

\section{RESEARCHES ON SPRUE.1}

$\mathrm{SPRUE}$ is a disease of chronic course, the main features of which are a frothy diarrhœa generally accompanied by a sore tongue; the disease as it progresses producing severe anæmia and exhaustion. The word sprue in English medical literature was first used by Manson in 1880 , and is apparently the anglicised form of the Dutch spruw. One would like to know something of the origin of this Dutch word. The form sproo was also used in the year 1825 in Scotland for "a disease affecting the mouth of very young children." This disease is in all probability the same as thrush, and it is important to note in this connection that the condition of the tongue in thrush is similar to that in sprue. The word thrush, the origin of which is obscure, is not known before the seventeenth century, when Pepys speaks of "a fever, a thrush, and a hickup." It may also be mentioned that sprue in Scotland was the term used for "that which is thrown off in casting metals" (scoria).

The present work deals with the disease in Ceylon, where "Ceylon sore mouth" is one of the names for the disease. There are no figures available to show its frequency in Europeans or in the natives in the island, but that it does occur in the latter in various countries appears to be fairly certain. It is apparently also a disease determined by long residence in the tropics, though on all these points one speaks with hesitation as accurate data are not available. That dysentery is a common predisposing cause there appears to be no doubt, but whether there is any other closer connection between the two diseases is doubtful.

A sore tongue is one of the features of sprue, and microscopically the epithelium is found to be desquamating. This dead epithelium is infiltrated with yeasts, and in some cases the yeast threads appear to be actually invading the living cells. This is not, however, found to be the case in the stomach or gut, which are also inflamed, though the gut contents contain masses of yeast, and yeasts are the commonest organisms in motions passed shortly before death. This infection of the gut contents with yeasts does not, however, occur in other wasting diseases, the author very properly having made adequate control observations. Yeasts, then, not only can be cultivated from the majority of sprue stools and salivas, but in the acute stage they are the most prevalent organisms in the tongue lesions, saliva. and motions.

Now thrush, a common disease of infants in temperate climates, is generally believed to be due to yeasts, and in some respects-e.g. atrophy of the tongue epithelium-resembles sprue. The author, indeed, inclines to the view that yeasts are in fact the cause of the disease. One might object, however, that if this were so one would expect sprue to be a far commoner disease than it is, as yeasts in the tropics are ubiquitous. The view held by some authors that it has affinities to scurvy is an "attractive" one, and is supported by the beneficial effect of a fruit diet such as strawberries or bael fruit. This work is an interesting record of a careful research, valuable although inconclusive in its results. The plate of

"A Report on Researches on Sprue in Ceylon, rgre-r4." By Dr. P. H. 7s. $6 d$. net. 
sprue tongues has the merit of clearness, although the colours are not those of nature. We feel sure it would "pay" the Planters' Association in Ceylon to employ permanently one or more medical men to investigate the subject further.

J. W. W. S.

\section{SCIENTIFIC COMMITTEES ON NATIONAL PROBLEMS.}

$\mathrm{W}^{\mathrm{E}}$ have referred from time to time to the various scientific committees appointed by the Government and scientific societies to deal with problems arising out of the war. It seems worth while to bring together now a list of such committees and a short statement of their work so far as that can be made known. It will be noticed that, with the exception of the Advisory Council of the Privy Council Committee and the Council and Committee of British Dyes (Ltd.), no provision is made for the payment of the experts in science and technology who are serving on other committees appointed by the Government and by scientific societies.

\section{Government Scientific Committees.}

The Board of Invention and Research appointed last July to assist the Admiralty in co-ordinating and encouraging scientific effort in relation to the requirements of the Naval Service consists of the following Central Committee and Panel of Consultants, who advise the main committee on questions referred to them :-

Central Committee: Admiral of the Fleet Lord Fisher of Kilverstone (president), Sir J. J. Thomson, Sir Charles A. Parsons, and Dr. G. T. Beilby. Panel : Prof H. B. Baker, Prof. W. H. Bragg, Prof. H. C. H. Carpenter, Sir William Crookes, Mr. W. Duddell, Prof. P. F. Frankland, Prof. B. Hopkinson, Sir Oliver Lodge, Prof. W. J. Pope, Sir Ernest Rutherford, Mr. G. Gerald Stoney, and the Hon. R. J. Strutt. Secretary and Naval Assistant: Captain

Thomas E. Crease, R.N.

We are informed by the Secretary of the Lords Commissioners of the Admiralty that the services of the members and the scientific experts on the Central Committee and the Panel of Consultants of the Board of Invention and Research are given gratuitously.

A Munitions Inventions Department of the Ministry of Munitions of War, with Mr. E. W. Moir as Comptroller, was appointed in August last to consider projects for inventions relating to munitions for warfare on land or matters pertaining thereto. The Advisory Panel of scientific and other experts is as follows:Prof. A. W. Crossley, Mr. Horace Darwin, Dr. S. Z. de Ferranti, Mr. A. MacDougall Duckham, Mr. W. Duddell, Dr. R. T. Glazebrook, Col. H. E. F. GooldAdams, Sir Robert A. Hadfield, Prof. J. S. Haldane, Col. N. B. Heffernan, Sir Alexander B. W. Kennedy, Mr. F. W. Lanchester, Prof. A. P. Laurie, Mr. Michael Longridge, Dr. W. H. Maw, Sir Hiram'S. Maxim, Capt. A. U. Moore, Sir Henry Norman, Bart., Dr. F. G. Ogilvie, Maj.-Gen. Sir George K. Scott-Moncrieff, Mr. F. Wilfrid S. Stokes, Mr. J. Swinburne, Sir J. J. Thomson, Mr. A. J. Walter, Mr. C. J. Wilson, and Lieut.-Col. J. C. Matheson. The secretary to the Advisory Panel is Mr. H. W. Dickinson, Munitions Inventions Department, Princes Street, Westminster, S.W.

The Comptroller of the Munitions Inventions Department assures $u$ s that these gentlemen are not paid and that their services in all cases are voluntary. $\mathrm{He}$ informs us further that the work of the Department is co-ordinated with that of the Board of Invention and Research, and that a constant interchange of information and ideas takes place.

No. 24 IO, VOL. 96$]$
In July last, Mr. Arthur Henderson, President of the Board of Education, issued a White Paper describing the Government scheme designed to establish a permanent organisation for the promotion of industrial and scientific research. A sum of $30,000 l$. has been provided for the purposes of the scheme during the first year. The circular points out that the scheme is in no way intended to replace or interfere with the arrangements which have been or may be made by the War Office or Admiralty or Ministry of Munitions to obtain scientific advice and investigation in connection with the provision of munitions of war. The scheme provides for the establishment of :(a) A Committee of the Privy Council responsible for the expenditure of any new moneys provided by Parliament tor scientific and industrial research; $(b)$ a small Advisory Council responsible to the Committee of Council and composed mainly of eminent scientific men and men actually engaged in industries dependent upon scientific research. The Committee of Council consists of the Lord President, the Chancellor of the Exchequer, the Secretary for Scotland, the President of the Board of Trade, the President of the Board of Education (who is to be vice-president of the Committee), the Chief Secretary for Ireland, together with such other Ministers and individual members of the Council as it may be thought desirable to add. The first non-official members of the Committee are:Lord Haldane, Mr. A. H. D. Acland, and Mr. J. A. Pease. The first members of the Advisory Council are :-Lord Rayleigh, Dr. G. T. Beilby, Mr. W. Duddell, Prof. B. Hopkinson, Prof. J. A. M'Celland, and $\mathrm{Mr}$. R. Threlfall, with Sir William S. M'Cormick as administrative chairman. The primary functions of the Advisory Council will be to advise the Committee of Council on (i) proposals for instituting specific researches; (ii) proposals for establishing or developing special institutions or departments of existing institutions for the scientific study of problems affecting particular industries and trades; (iii) the establishment and award of research studentships and fellowships. The Advisory Council will also be available, if requested, to advise the several Education Departments as to the steps which should be taken for increasing the supply of workers competent to undertake scientific research. It is contemplated that the Advisory Council will work largely through sub-committees reinforced by suitable experts in the particular branch of science or industry concerned. In pursuance of the Order in Council, the Treasury has authorised the payment of remuneration to the members of the Advisory Council.

The Minister of Munitions of War, with the concurrence of the Home Secretary, has appointed a committee to consider and advise on questions of industrial fatigue, hours of labour, and other matters affecting the personal health and physical efficiency of workers in munition factories and workshops. The committee is constituted as follows:-Sir George Newman (chairman); Sir Thomas Barlow, Bart., Mr. G. Bellhouse, Prof. A. E. Boycott, Mr. J. R. Clynes, Mr. E. L. Collis, Dr. W. M. Fletcher, Prof. Leonard E. Hill, Mr. Samuel Osborn, Miss R. E. Squire, and Mrs. H. J. Tennant.

The president of the Board of Agriculture and Fisheries has appointed a committee (consisting of Lord Middleton (chairman), Mr. Henry Chaplin, Sir Ailwyn Fellowes, the Hon. Alexander Parker, Major Sir M. Burrell, Bart., Sir G. Greenall, Bart., and Capt. M. S. Adye) to consider and advise the Board as to the steps which should be taken to secure the production and maintenance in England and Wales of a supply of horses suitable and sufficient for military purposes, especially on mobilisation. 